\title{
Sustainable Methods for Decontamination of Microcystin in Water Using Cold Plasma and UV with Reusable $\mathrm{TiO}_{2}$ Nanoparticle Coating
}

\author{
Xuewen Jiang ${ }^{1}$, Seungjun Lee ${ }^{2}$, Chulkyoon Mok ${ }^{3}$ and Jiyoung Lee ${ }^{1,2,3, *}$ \\ 1 Department of Food Science and Technology, The Ohio State University, Columbus, OH 43210, USA; \\ jiang.1188@osu.edu \\ 2 Environmental Science Graduate Program, The Ohio State University, Columbus, OH 43210, USA; \\ lee.5178@osu.edu \\ 3 Department of Food Science and Biotechnology, Gachon University, Seongnam 13557, Korea; \\ mokck@gachon.ac.kr \\ * Correspondence: lee.3598@osu.edu; Tel.: +1-614-292-5546 \\ Academic Editor: Mu Naushad \\ Received: 14 February 2017; Accepted: 21 April 2017; Published: 5 May 2017
}

\begin{abstract}
Microcystins (MCs) are a family of cyanotoxins and pose detrimental effects on human, animal, and ecological health. Conventional water treatment processes have limited success in removing MCs without producing harmful byproducts. Therefore, there is an urgent need for cost-effective and environmentally-friendly methods for treating MCs. The objective of this study was to develop sustainable and non-chemical-based methods for controlling MCs, such as using cold plasma and ultra violet (UV) light with titanium dioxide $\left(\mathrm{TiO}_{2}\right)$ coating, which can be applied for diverse scale and settings. MCs, extracted from Microcystis aeruginosa, were treated with cold plasma or UV at irradiance of $1470 \mu \mathrm{W} / \mathrm{cm}^{2}$ (high) or $180 \mu \mathrm{W} / \mathrm{cm}^{2}$ (low). To assess synergistic effects, the outside of the UV treatment chamber was coated with nanoparticles $\left(\mathrm{TiO}_{2}\right)$ prior to irradiation, which can be reused for a long time. The degradation efficiency of UV was enhanced by the reusable $\mathrm{TiO}_{2}$ coating at lower irradiance $\left(70.41 \%[\mathrm{UV}]\right.$ vs. $\left.79.61 \%\left[\mathrm{UV}+\mathrm{TiO}_{2}\right], 120 \mathrm{~min}\right)$, but no significant difference was observed at higher irradiance. Cold plasma removed MCs rapidly under experimental conditions $(92 \%, 120 \mathrm{~min})$, indicating that it is a promising candidate for controlling MCs in water without generating harmful disinfection byproducts. It can be also easily and practically used in household settings during emergency situations.
\end{abstract}

Keywords: Microcystis aeruginosa; cyanotoxin; cold plasma; UV; titanium dioxide; emergency preparedness

\section{Introduction}

Microcystins (MCs) refer to a family of cyanotoxins produced by cyanobacteria, such as Microcystins spp., Anabaena spp., Nodularia spp., and several other cyanobacterial species [1]. They are commonly found worldwide in surface waters [2,3]. MCs can cause headache, sore throat, vomiting, nausea, stomachache, diarrhea, and pneumonia in acute exposure [4]. Chronic exposure can lead to liver, kidney, and reproductive system damage and promote cancerous tumors [5,6]. Multiple pathways are involved in MC exposure, such as direct ingestion, inhalation of bioaerosol, or dermal contact of contaminated water [3,7]. According to the World Health Organization (2011) MCs are safe to consume in drinking water at levels of 1 part per billion (ppb) and to exposure in recreational water at $10 \mathrm{ppb}$ [8]. United States Environmental Protection Agency (USEPA) listed MCs as one of the highest priority for health risks in drinking water [9]. New USEPA guidelines for MC-LR (2015) 
suggest a maximum acceptable concentration in drinking water of $0.3 \mathrm{ppb}$ for pre-school-age-children and $1.6 \mathrm{ppb}$ for school-age-children and adults [10], and $4 \mathrm{ppb}$ for recreational water [11]. However, traditional water treatment steps-including coagulation, sedimentation, and disinfection-have demonstrated limited effect on removing MCs during heavy bloom periods [12]. Furthermore, MCs are resistant to direct UV exposure, ozone, or chlorine oxidation (common steps for disinfection in drinking water treatment) and the toxins may cause health risk for water users [13-16]. For example, MCs were detected ( 2.5 ppb) in the finished drinking water in Toledo, Ohio in August 2014 [10].

Plenty of research has been done on MC degradation using physical, chemical, and biological methods, such as UV irradiation at different wavelength [14,17]; chemical oxidants [16,18], and microcystin-degrading bacteria [19]. However, most previous research focused on a single variant or artificial mixture of MCs, which could have different degradation dynamics and toxicity from natural MC mixture [20]. Therefore, there is a critical need for developing more environmentally-friendly and effective methods for controlling MC contamination to protect both public health and water/food safety, especially because harmful algal blooms are expected to be more frequent and intensive globally $[21,22]$.

In this study, we introduced two novel techniques, cold plasma and nanoparticle application with $\mathrm{UV}$, to examine the effects of both methods for removing MCs in water. Plasma is ionized gas at normal temperature with non-selective short half-life of active species, such as $\bullet \mathrm{OH}$, which can degrade pollutants rapidly without generating toxic residuals [23-26]. It has been known to be effective to remove chemical contaminants in aqueous phase (e.g., wastewater treatment) [27-29], and been used to ensure food safety, especially in fresh produce, by inactivating the microorganisms and removing pesticide residuals [30-32]. Barillas et al. (2015) [33] described the capital cost of plasma was $20 \%$ less than a traditional wastewater plant. It has been also reported that cold plasma can lower the energy consumption in food industries. However, this technology has not been widely applied for MC degradation. This method only requires water itself during MC treatment, therefore it can be perceived as clean and harmless to both treated objectives and operators, which makes it as a promising alternative to current water treatment methods, possibly for fresh produce application as well.

For nanoparticle application, $\mathrm{TiO}_{2}$ has been widely used in wastewater treatment and disinfection. UV illumination induces hydroxyl radicals produced from the active electron and positive hole of $\mathrm{TiO}_{2}$, which reacts with pollutants in water $[34,35]$. It was reported that $\mathrm{TiO}_{2}$ showed a great photocatalytic activity to enhance the degradation rate of $\mathrm{MC}$-LR with $\mathrm{UV}[20,36]$. The $\mathrm{UV} / \mathrm{TiO}_{2}$ wastewater treatment is effective and cost efficient, but increases by further separation of $\mathrm{TiO}_{2}$ in the effluent [37]. In this study, the effectiveness of UV with outer coated $\mathrm{TiO}_{2}$ has been evaluated to improve the efficiency of entire treatment, as well as lower the cost of separation. $\mathrm{TiO}_{2}$ coating is anticipated to be a time- and cost-effective, safe, and sustainable method of MC treatment when combined with UV irradiation.

The objective of this research was to develop and evaluate sustainable and effective methods for MC treatment by cold plasma and UV with $\mathrm{TiO}_{2}$. This research describes, for the first time, the effectiveness of cold plasma and UV combined with $\mathrm{TiO}_{2}$ coating for total MC (mixture of MC congeners extracted from M. aeruginosa that was isolated from Lake Erie) degradation.

\section{Materials and Methods}

\subsection{Preparation}

MCs were extracted from Microcystis aeruginosa (identified by targeting PC-IGS and mcyA genes [38]) that was isolated from Lake Erie. M. aeruginosa was cultured in CT medium [39] using sonication (three cycles of 5-min sonication followed by 10-min rest) with a Sonic Dismembrator (50 watts, Fisher Scientific Model F50 with Probe, Waltham, MA, USA). Then, three cycles of freeze-thaw lysis were applied, and the extracted solutions was filtered with sterile $0.45 \mu \mathrm{m}$ pore-size membrane (MF-Millipore Membrane Filter, mixed cellulose esters, Billerica, MA, USA) to remove bacterial cells [40]. 


\subsection{Treatments and Measurement}

MCs solution was diluted with deionized (DI) water to final concentration of $10 \mathrm{ppb}$ at $\mathrm{pH}$ 7.4, EC -17 mV (Mettler-Toledo AG, Analytical. CH-8603, Schwerzenbach, Switzerland). A $\mathrm{TiO}_{2}$ nanopowder solution was made in Tween 20 (Boston BioProducts, Ashland, MA, USA): isopropanol (Fisher Scientific, Waltham, MA, USA): acetic acid (Fisher Scientific, USA): $\mathrm{TiO}_{2}$ (particle size: $21 \mathrm{~nm}$, Aldrich Chemistry, St. Louis, MO, USA) = 1:45:6:1 by weight) [41], applied $\sim 30 \mathrm{~mL}$ of the $\mathrm{TiO}_{2}$ nanopowder solution evenly to the outside of a glass container (dimension: $22.5 \mathrm{~cm} \times 33 \mathrm{~cm} \times 5.4 \mathrm{~cm}$ [width $\times$ length $\times$ height], capacity: $2.8 \mathrm{~L}$, materials: tempered soda-lime glass, PYREX ${ }^{\circledR}$ ), and dried at $25^{\circ} \mathrm{C}$ (about two hours) to test the synergistic effect with UV. The UV irradiances were adjusted by the distance between the lamp and targets, and measured with UVC digital light meter (General Tools UV512C, Secaucus, NY, USA) at the central point of the treated water surface. One liter of MC solution was treated with different conditions of application with constant stirring: (1) UV irradiation system (UV-C $254 \mathrm{~nm}$ lamp, G15T8, $15 \mathrm{~W}$, Philips, Hamburg, Germany) at $1470 \mu \mathrm{W} / \mathrm{cm}^{2}$ (high irradiance) for $90 \mathrm{~min}$ (pre-test showed that $\mathrm{MC}$ concentration was below the detection limit after $90 \mathrm{~min}$ treatment, data not shown); (2) UV at $180 \mu \mathrm{W} / \mathrm{cm}^{2}$ (low irradiance) for $120 \mathrm{~min}$; (3) $\mathrm{UV}$ with $\mathrm{TiO}_{2}$ at $1470 \mu \mathrm{W} / \mathrm{cm}^{2}$ (high irradiance) for $90 \mathrm{~min}$ (pre-test showed that MC concentration was below the detection limit after 90 min treatment, data not shown); (4) $\mathrm{UV}$ with $\mathrm{TiO}_{2}$ at $180 \mu \mathrm{W} / \mathrm{cm}^{2}$ (low irradiance) for $120 \mathrm{~min}$; (5) cold plasma (Cleaz one-touch water sterilizer, CSOL-200SL, $220 \mathrm{~V}, 60 \mathrm{~Hz}, 80 \mathrm{~W}$, Haan Co., Seoul, Korea) for $120 \mathrm{~min}$; (6) without treatment in dark room for $120 \mathrm{~min}$ (control group) (Figure 1). Samples were taken at specific time interval. Total MC concentrations were measured with Microcystins-ADDA enzyme-linked immunosorbent assay (ELISA) kits (Abraxis, Warminster, PA, USA) in duplicate as Ohio EPA described [42]. Under the same conditions, three sets of each type of treatment were performed.

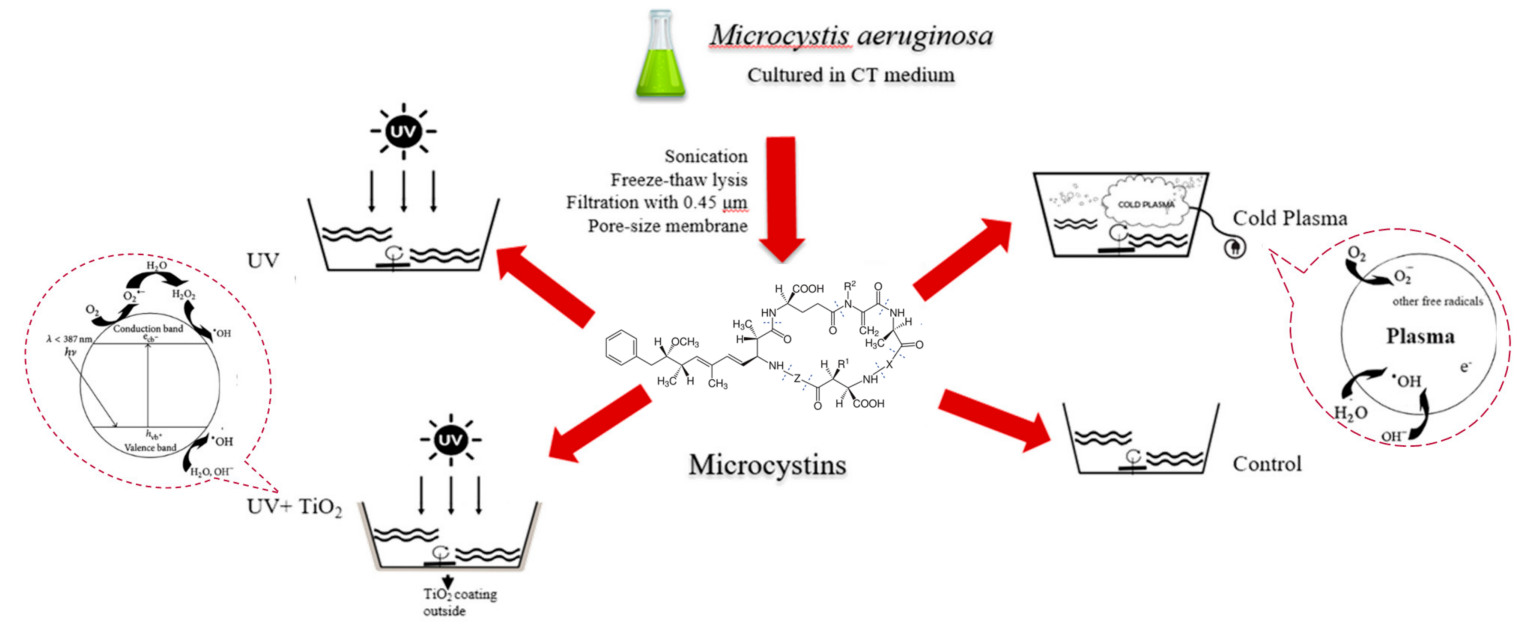

Figure 1. Schematic diagram of MC treatment in this study.

\subsection{Statistical Analysis}

To evaluate toxin degradation, the data were analyzed by one-way analysis of variance (ANOVA) using SPSS Statistics 22 statistical software (IBM, Armonk, NY, USA). For the toxin degradation kinetics, each treatment data was fitted in first- and second-order reaction models.

\subsection{Energy per Order $\left(E_{E O}\right)$ of Each Treatment}

Energy per order $\left(\mathrm{E}_{\mathrm{EO}}\right)$ of each treatment was calculated as the equation below [43].

$$
\mathrm{E}_{\mathrm{EO}}=\frac{P t \times 1000}{V \lg \left(\frac{C_{i}}{C_{f}}\right)}=\frac{38.4 \times P}{V k}
$$


where $P$ is the power of equipment $(\mathrm{kW}), V$ is the volume of water $(\mathrm{L})$ and $k$ is the rate constant calculated in first-order model.

\section{Results}

\subsection{Synergistic Effects of $\mathrm{TiO}_{2}$ with $\mathrm{UV}$ on $\mathrm{MC}$ Degradation}

With high irradiance $\left(1470 \mu \mathrm{W} / \mathrm{cm}^{2}\right)$ of UV illumination, $69.5 \%$ (10 $\left.\mathrm{min}\right), 93.1 \%$ (30 $\left.\mathrm{min}\right)$, and $97.6 \%$ (90 $\mathrm{min}$ ) of microcystins in the solution were degraded as the exposure time increased. With the $\mathrm{UV}$ and $\mathrm{TiO}_{2}, \mathrm{MCs}$ were removed by $69.4 \%$ (10 $\left.\mathrm{min}\right), 90.5 \%$ (30 $\mathrm{min}$ ), and $98.1 \%$ (90 min), respectively. No significant enhancement by $\mathrm{TiO}_{2}$ was observed under this high UV irradiance condition $(p>0.05)$ (Figure 2a).

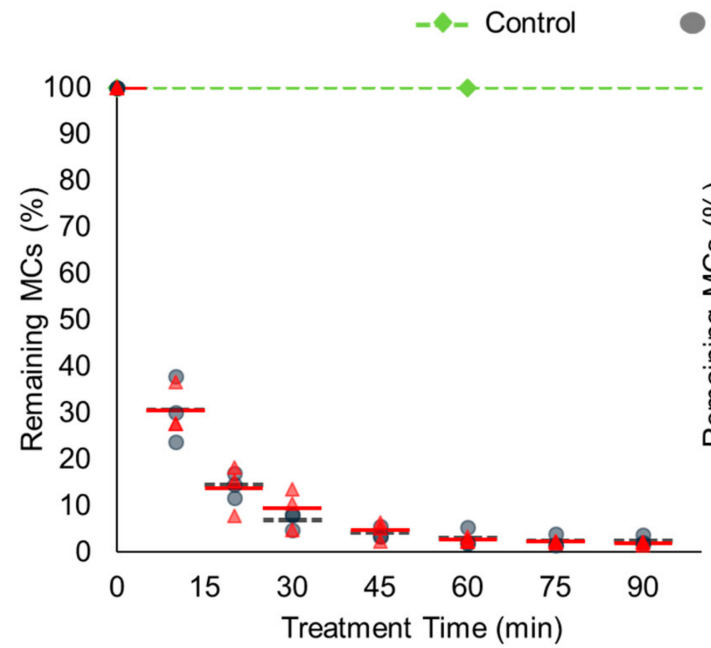

(a)

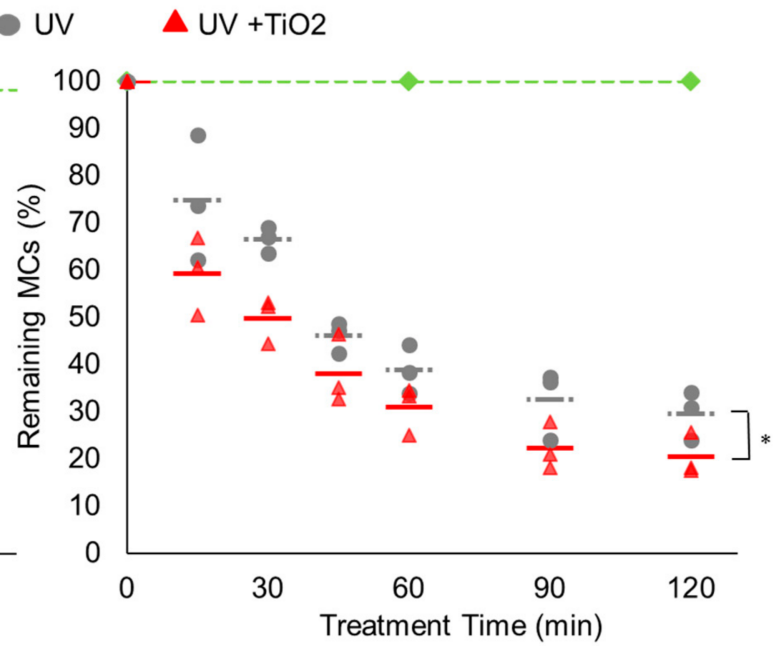

(b)

Figure 2. The $\mathrm{MC}$ degradation rate in water treated with $\mathrm{UV}$ and $\mathrm{UV} / \mathrm{TiO}_{2}$. Microcystins (final concentration of $10 \mathrm{ppb}$ ) were treated with UV (black circle) and UV with $\mathrm{TiO}_{2}$ coating outside (red triangle) under high irradiance $\left(1470 \mu \mathrm{W} / \mathrm{cm}^{2}\right)$ for $90 \mathrm{~min}$ and low irradiance $\left(180 \mu \mathrm{W} / \mathrm{cm}^{2}\right.$ ) for $120 \mathrm{~min}$ with constant stirring. The control was without UV irradiation in a dark room for $120 \mathrm{~min}$ (green diamond). Results represent three independent sets of duplicate measurements. The average of three sets was expressed with line. (a) high irradiance $\left(1470 \mu \mathrm{W} / \mathrm{cm}^{2}\right)$; (b) low irradiance $\left(180 \mu \mathrm{W} / \mathrm{cm}^{2}\right)$ treatment.

With low irradiance $\left(180 \mu \mathrm{W} / \mathrm{cm}^{2}\right)$ UV illumination, 33.5\% (30 $\left.\mathrm{min}\right), 61.3 \%$ (60 $\left.\mathrm{min}\right), 67.5 \%$ (90 $\mathrm{min}$ ), and $70.4 \%$ (120 $\mathrm{min}$ ) of MCs were degraded as the exposure time increased, but the degrees of $\mathrm{MC}$ degradation were lower at each exposure time when compared to the high irradiance (Figure 2b). However, $\mathrm{TiO}_{2}$ coating on the outside of the UV treatment container showed a significant improvement in removing MCs at this UV irradiance ( $p<0.05)$ : 50.2, 69.1, 77.7, and 79.6\% at each exposure time, respectively. These results show that UV irradiance is one of the major factors affecting the MCs degradation effectiveness and higher irradiance could accelerate the removal of MCs. However, at lower irradiance, the addition of $\mathrm{TiO}_{2}$ significantly enhanced the $\mathrm{MC}$ remediation.

\subsection{Effectiveness of Cold Plasma on MC Degradation}

MCs were removed by $66.2 \%$ (30 $\mathrm{min}$ ), 80.2\% (60 $\mathrm{min}$ ), 86.8\% (90 $\mathrm{min}$ ), and 92.0\% (120 $\mathrm{min}$ ) using cold plasma (Figure 3). The MC degradation rate was faster than low irradiance UV illumination (with or without $\left.\mathrm{TiO}_{2}\right)(p<0.05)$. This result demonstrates that cold plasma can be a promising candidate for future treatment of MCs. The raw data are shown in Appendix A Table A1. 


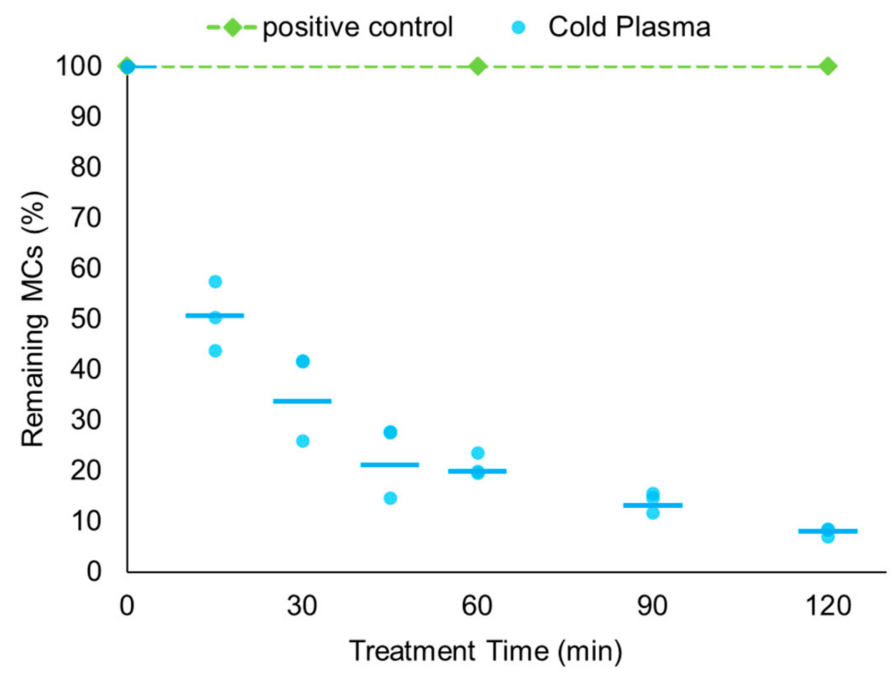

Figure 3. The MC degradation rate in water treated with cold plasma. Microcystins (final concentration of $10 \mathrm{ppb}$ ) were treated with cold plasma (blue circle) for $120 \mathrm{~min}$ or put in a dark room (as a control) (green diamond) with constant stirring. Results represent three independent sets of duplicate measurements. The average of three sets was expressed as line.

\subsection{Kinetic Analysis}

To better understand the kinetics of MC degradation with different types of treatments, two different models, first-order-reaction and second-order-reaction, were used, where $k$ is the rate constants for the first-order and the second-order reaction kinetics; $\mathrm{R}^{2}$ is the corresponding correlation coefficient; $t_{\frac{1}{2}}$ represents the half-life of microcystins under certain experimental conditions (Tables 1 and 2).

Both the first-order and second-order models could approximately describe the kinetics of all the treatments (Table 1). It was apparent that the $k$ of the high irradiance group of UV treatment was much higher (about four times higher in first-order) than that of the low irradiance group of UV treatment, which indicated that the degradation of MCs by UV irradiation was dose-dependent. After comparing UV with $\mathrm{UV} / \mathrm{TiO}_{2}$ at low irradiance, the rate constant of the latter was found to be higher and half-lives were shorter, indicating a more rapid degradation with $\mathrm{TiO}_{2}$ coating.

Table 1. Degradation rate constants $(k)$ and half-lives $\left(t_{\frac{1}{2}}\right)$ in the first- or second-order reaction kinetics in microcystin removal by $\mathrm{UV}$ and $\mathrm{UV}$ with $\mathrm{TiO}_{2}$.

\begin{tabular}{|c|c|c|c|c|}
\hline \multirow{2}{*}{ Treatment } & \multicolumn{3}{|c|}{ First-order $\left(\operatorname{Ln}\left(\mathrm{C}_{0} / \mathrm{C}\right)=-k \mathrm{t}\right)$} & \multirow{2}{*}{ Reference } \\
\hline & $k\left(\min ^{-1}\right)$ & $\mathbf{t}_{\frac{1}{2}}(\min )$ & $\mathbf{R}^{2}$ & \\
\hline UV (Irradiance: $1470 \mu \mathrm{W} / \mathrm{cm}^{2}$ ) & 0.0394 & 17.59 & 0.89 & This study \\
\hline UV with $\mathrm{TiO}_{2}$ (Irradiance: $1470 \mu \mathrm{W} / \mathrm{cm}^{2}$ ) & 0.0412 & 16.82 & 0.91 & This study \\
\hline UV (Irradiance: $180 \mu \mathrm{W} / \mathrm{cm}^{2}$ ) & 0.0104 & 66.64 & 0.92 & This study \\
\hline UV with $\mathrm{TiO}_{2}$ (Irradiance: $180 \mu \mathrm{W} / \mathrm{cm}^{2}$ ) & 0.0129 & 53.73 & 0.93 & This study \\
\hline $\begin{array}{l}\text { UV with } \mathrm{TiO}_{2} \text { added }(\sim 182 \mathrm{ppb} \text { MC-LA; } \\
\left.\qquad 4,100 \mu \mathrm{W} / \mathrm{cm}^{2}\right)\end{array}$ & 0.0277 & 25.02 & 0.99 & [29] \\
\hline \multirow{2}{*}{ Treatment } & \multicolumn{3}{|c|}{ Second-order $\left(1 / C-1 / C_{0}=k t\right)$} & \multirow{2}{*}{ Reference } \\
\hline & $k(\mathrm{ppb} \times \min )^{-1}$ & $\mathbf{t}_{\frac{1}{2}}(\min )$ & $\mathbf{R}^{2}$ & \\
\hline UV (Irradiance: $1470 \mu \mathrm{W} / \mathrm{cm}^{2}$ ) & 0.0848 & 1.74 & 0.92 & This study \\
\hline UV with $\mathrm{TiO}_{2}$ (Irradiance: $1470 \mu \mathrm{W} / \mathrm{cm}^{2}$ ) & 0.0913 & 1.58 & 0.95 & This study \\
\hline UV (Irradiance: $180 \mu \mathrm{W} / \mathrm{cm}^{2}$ ) & 0.0025 & 46.34 & 0.91 & This study \\
\hline UV with $\mathrm{TiO}_{2}$ (Irradiance: $180 \mu \mathrm{W} / \mathrm{cm}^{2}$ ) & 0.0028 & 28.09 & 0.93 & This study \\
\hline
\end{tabular}


For cold plasma, the obtained $\mathrm{R}^{2}$ was almost the same for both models (Table 2). The rate constant of cold plasma was $0.0192 \mathrm{~min}^{-1}$ in first-order model and $0.0145(\mathrm{ppb} \times \mathrm{min})^{-1}$ in second-order model, demonstrating a high effectiveness for removing MCs. Compared to low-irradiance UV treatment, cold plasma significantly enhanced the MC degradation rate in both models $(p<0.01)$.

Table 2. Degradation rate constants $(k)$ and half-lives $\left(\mathrm{t}_{\frac{1}{2}}\right)$ in the first- or second-order reaction kinetics in microcystin removal by cold plasma.

\begin{tabular}{|c|c|c|c|c|}
\hline \multirow{2}{*}{ Treatment } & \multicolumn{3}{|c|}{ First-order $\left(\operatorname{Ln}\left(\mathrm{C}_{0} / \mathrm{C}\right)=-k \mathrm{t}\right)$} & \multirow{2}{*}{ Reference } \\
\hline & $k\left(\min ^{-1}\right)$ & $\mathbf{t}_{\frac{1}{2}}(\min )$ & $\mathbf{R}^{2}$ & \\
\hline Cold plasma & 0.0192 & 36.10 & 0.95 & This study \\
\hline \multirow{2}{*}{ Treatment } & \multicolumn{3}{|c|}{ Second-order $\left(1 / C-1 / C_{0}=k t\right)$} & \multirow{2}{*}{ Reference } \\
\hline & $k(\mathrm{ppb} \times \mathrm{min})^{-1}$ & $\mathbf{t}_{\frac{1}{2}}(\min )$ & $\mathbf{R}^{2}$ & \\
\hline Cold plasma & 0.0150 & 10.88 & 0.93 & This study \\
\hline $\begin{array}{l}\text { Glow discharge plasma } \\
\text { (4025.5 ppb MC-LR) }\end{array}$ & 38.81 & 0.018 & Not mentioned & {$[44]$} \\
\hline
\end{tabular}

\subsection{Energy per Order ( $\left.E_{E O}\right)$}

Energy cost of each treatment (in first-reaction model) is shown in Table 3. Energy per order $\left(\mathrm{E}_{\mathrm{EO}}\right)$ is electrical energy (in kilowatt-hours, $\mathrm{kWh}$ ) required to reduce the concentration of a pollutant by one order of magnitude $(90 \%)$ in $1 \mathrm{~L}$ of contaminated water [43]. The high irradiance of UV-associated treatments cost the least energy, then followed by cold plasma, $\mathrm{UV}$ with $\mathrm{TiO}_{2}$ at low irradiance, and $\mathrm{UV}$ alone at low irradiance. Overall, as a non-chemical based treatment, the $\mathrm{TiO}_{2}$ coating with $\mathrm{UV}$ costs less energy than previous methods [45].

Table 3. Energy per order $\left(\mathrm{E}_{\mathrm{EO}}\right)$ of each treatment.

\begin{tabular}{ccc}
\hline Treatment & E $_{\mathrm{EO}}\left(\mathbf{k W h} / \mathbf{m}^{\mathbf{3}}\right.$ /order) & Reference \\
\hline UV $\left(\right.$ Irradiance: $\left.1470 \mu \mathrm{W} / \mathrm{cm}^{2}\right)$ & 27.96 & This study \\
UV with $\mathrm{TiO}_{2}$ (Irradiance: $\left.1470 \mu \mathrm{W} / \mathrm{cm}^{2}\right)$ & 29.85 & This study \\
$\mathrm{UV}\left(\mathrm{Irradiance}^{2} 180 \mu \mathrm{W} / \mathrm{cm}^{2}\right)$ & 110.73 & This study \\
UV with $\mathrm{TiO}_{2}$ (Irradiance: $\left.180 \mu \mathrm{W} / \mathrm{cm}^{2}\right)$ & 89.26 & This study \\
$\mathrm{UV}$ with $\mathrm{TiO}_{2}$ added & 415.71 & {$[45]$} \\
Cold plasma & 59.97 & This study \\
\hline
\end{tabular}

\section{Discussion}

Previous research on MC degradation focused on specific variants of MCs, such as MC-LR or RR [46-48]. Qiao et al. (2005) demonstrated that $\mathrm{H}_{2} \mathrm{O}_{2}$ enhanced the degradation of MC-RR under UV illumination [47]. In real world situations, a mixture of MC congeners ( $>100$ types) were found to be released into surface water [49], which might suggest different resistance and kinetics to those current treatments. He et al. (2015) [14] investigated the relative susceptibility of various amino acids of MCs to UV treatment (with hydroxyl radical) and they found that MC-YR was the most susceptible and MC-LA was more resistant than MC-LR and -RR. In this study, natural extracts of MCs released from $M$. aeruginosa were used to mimic the toxin residuals in natural blooms, which contains multiple variants of microcystins (detected by LC/MS, data not shown). Ohio EPA (2015) recommended ELISA as a rapid detection method recommended to quantify total microcystins regardless of the congeners, and similar level of MC concentration measured by ELISA, LC-MS/MS, and LC-UV was obtained [42,50]. Therefore, due to its ability to measure multiple MC variants, ELISA was one of the best options to collectively measure the MCs. 
UV, as a traditional disinfection method in water treatment plants, has been evaluated for MC degradation [51]. As the results herein show, the irradiance of UV highly affects its effectiveness. At high irradiance, UV alone could rapidly degrade MCs in a short time, whereas a low irradiance UV less effectively removed MCs. However, the general requirement of UV irradiance for water treatment is two order of magnitude lower than the experimental condition of high irradiance. Previous studies added $\mathrm{TiO}_{2}$ directly into the water that is treated as a catalyst. $\mathrm{TiO}_{2}$ in the water may cause another contamination problem since there might be unpredictable hazards when exposed to the excessive $\mathrm{TiO}_{2}$ and using the $\mathrm{TiO}_{2}$ increases the treatment cost. In this study, the synergistic effect of $\mathrm{TiO}_{2}$ under $\mathrm{UV}$ irritation was tested by coating the outer surface of the container, which improved public perception by preventing the release of the $\mathrm{TiO}_{2}$ into the treated water. In addition, this type of application maximizes the reusability of $\mathrm{TiO}_{2}$, thereby it can reduce the cost of each treatment and lower the risk of environmental contamination of these nanoparticles. Meanwhile, the coating method saved the cost for removing the nanoparticles from the treated water compared to other $\mathrm{TiO}_{2}$ treatment method (nanoparticles were added in water). The saved cost was not reflected in the $\mathrm{E}_{\mathrm{EO}}$ calculation. As shown in the results, lower UV dose was still effective in removing MCs due to the synergistic effect of $\mathrm{TiO}_{2}$ (additional 17\% (30 min) and 9\% MC (120 min) removal). Therefore, $\mathrm{TiO}_{2}$ coating could shorten UV irradiation time to achieve a desired MC degradation efficiency at a relatively low UV irradiance. In addition, compared to Sampaio et al. (2015) [45] (high irradiance of UV $\left(47,100 \mu \mathrm{W} / \mathrm{cm}^{2}\right.$ ) with $\mathrm{TiO}_{2}$ into water directly), our remediation treatment (UV at $180 \mu \mathrm{W} / \mathrm{cm}^{2}$ with surface coated $\mathrm{TiO}_{2}$ ) was still effective (constant of first-order reaction) in removing MC degradation in water (Table 1). Therefore, the coating method can be considered as an alternative to direct addition when removing cyanotoxins in a sustainable and environmental friendly way in various water treatment settings.

Cold plasma is a safe and rapid treatment that is applicable for various situations with different scales and materials [44]. Compared to chemical-based methods, such as chlorination, Zhang et al. (2012) [44] demonstrated that the intermediates and end-products produced during MC degradation by plasma treatment were non-toxic. Previous studies [44,48] demonstrated that plasma was effective for removal of MC-LR by attacking the conjugated carbon double bonds of the Adda structure. Zhang et al. (2012) [44] showed that glow discharge plasma can degrade MC-LR with a rate constant of $38.81 \mathrm{ppb}^{-1} \mathrm{~min}^{-1}$ in second-order model (Table 2). This study is the first to confirm the effectiveness in MC degradation while using the natural mixture of MCs derived from the toxic M. aeruginosa that was isolated from the harmful bloom in Lake Erie.

When compared with the $\mathrm{UV}+\mathrm{TiO}_{2}$ (low UV irradiance), the cold plasma treatment showed additional 16\% (30 $\mathrm{min}$ ) and $12 \%(120 \mathrm{~min}$ ) of MCs removal at the same exposure times under the study conditions. Therefore, cold plasma treatment can shorten the MC treatment time further, which will be quite useful and impactful, especially during a high bloom period and under an emergency when toxins in the water need to be treated in a timely manner. The $\mathrm{E}_{\mathrm{EO}}$ of cold plasma was lower than $\mathrm{UV}$ and $\mathrm{UV} / \mathrm{TiO}_{2}$ at low irradiance. The treatment time can be further shortened if the levels of MC are relatively low, indicating that it could serve as a practical backup for family treatment. For example, when municipal water treatment cannot meet the USEPA guideline in drinking water (e.g., Toledo water crisis in 2014), cold plasma can be immediately used to treat the MCs in tap water in affected families. In water treatment plants, large-scale application might improve effectiveness further to achieve the same degradation effects in a shorter period. Previous studies demonstrated that powerful disinfection using cold plasma in fresh produce can be achieved without generating extra heat and destruction of food quality [23,52-54]. Moreover, the cold plasma did not require any reagents beyond air and water, therefore it is a green technology without generation of harmful waste and unwanted byproducts. However, few studies have been conducted on investigating the feasibility of cold plasma application in MC removal in food, which is another critical exposure route to cyanotoxins [55]. Combining the results from this study, it is promising to test the effectiveness of cold plasma for degrading MCs accumulated in fresh produce, fish, and other food-related matrices. Therefore, more efforts should be made in MC decontamination in food in the future. 


\section{Conclusions}

This study reports the effectiveness of total MC degradation using sustainable cold plasma and $\mathrm{TiO}_{2}$ coating. The UV irradiation combined with $\mathrm{TiO}_{2}$-coating can enhance the effectiveness of MC degradation. Our developed technique prevents the direct contact between $\mathrm{TiO}_{2}$ and water to avoid unwanted contamination. In addition, the cold plasma degraded the toxin effectively without generating harmful byproducts. The cold plasma can be a promising application for both household and industry settings, using different scales of equipment. In future studies, other analytical tools other than ELISA and toxicity tests are recommended to identify the potential changes in the composition of microcystins and intermediates after each type of toxin treatment. It can also be practically used in household settings during emergency situations.

Author Contributions: Jiyoung Lee and Chul Kyoon Mok conceived and designed the experiments. Xuewen Jiang conducted the experiments and analyzed the data. Seungjun Lee assisted in toxin measurements and experiments. Xuewen Jiang and Seungjun Lee drafted the manuscript and Jiyoung Lee and Chul Kyoon Mok revised it. Jiyoung Lee supervised the study throughout the study period. All authors significantly contributed to the intellectual content and approved the paper.

Conflicts of Interest: The authors declare no conflict of interest.

\section{Appendix A}

Table A1. Concentrations of MC remained in the water after the treatments.

\begin{tabular}{|c|c|c|c|c|}
\hline \multirow[b]{2}{*}{ Concentrstion (ppb) } & \multirow{3}{*}{0} & \multirow{3}{*}{30} & \multirow{3}{*}{90} & \multirow{3}{*}{120} \\
\hline & & & & \\
\hline Treatment & & & & \\
\hline UV (Irradiance: $1470 \mu \mathrm{W} / \mathrm{cm}^{2}$ ) & $6.76 \pm 1.50$ & $0.48 \pm 0.15$ & $0.16 \pm 0.03$ & \multirow[b]{2}{*}{$\mathrm{N} / \mathrm{A}$} \\
\hline UV with $\mathrm{TiO}_{2}$ (Irradiance: $1470 \mu \mathrm{W} / \mathrm{cm}^{2}$ ) & $6.95 \pm 0.92$ & $0.66 \pm 0.34$ & $0.13 \pm 0.016$ & \\
\hline UV (Irradiance: $180 \mu \mathrm{W} / \mathrm{cm}^{2}$ ) & $8.63 \pm 0.0$ & $5.74 \pm 0.24$ & $2.81 \pm 0.64$ & $2.55 \pm 0.45$ \\
\hline UV with $\mathrm{TiO}_{2}$ (Irradiance: $180 \mu \mathrm{W} / \mathrm{cm}^{2}$ ) & $12.72 \pm 0.0$ & $6.33 \pm 0.61$ & $2.83 \pm 0.63$ & $2.59 \pm 0.58$ \\
\hline Cold plasma & $6.13 \pm 0.78$ & $2.20 \pm 0.45$ & $0.85 \pm 0.12$ & $0.50 \pm 0.11$ \\
\hline
\end{tabular}

\section{References}

1. Cheung, M.Y.; Liang, S.; Lee, J. Toxin-producing cyanobacteria in freshwater: A review of the problems, impact on drinking water safety, and efforts for protecting public health. J. Microbiol. 2013, 51, 1-10. [CrossRef] [PubMed]

2. Harke, M.J.; Steffen, M.M.; Gobler, C.J.; Otten, T.G.; Wilhelm, S.W.; Wood, S.A.; Paerl, H.W. A review of the global ecology, genomics, and biogeography of the toxic cyanobacterium, Microcystis spp. Harmful Algae 2016, 54, 4-20. [CrossRef] [PubMed]

3. Funari, E.; Testai, E. Human health risk assessment related to cyanotoxins exposure. Crit. Rev. Toxicol. 2008, 38, 97-125. [CrossRef] [PubMed]

4. Lévesque, B.; Gervais, M.; Chevalier, P.; Gauvin, D. Prospective study of acute health effects in relation to exposure to cyanobacteria. Sci. Total 2014, 466, 397-403. [CrossRef] [PubMed]

5. Rudolph-Böhner, S.; Mierke, D.; Moroder, L. Molecular structure of the cyanobacterial tumor-promoting microcystins. FEBS Lett. 1994, 349, 319-323. [CrossRef]

6. Dawson, R.M. The toxicology of microcystins. Toxicon 1998, 36, 953-962. [CrossRef]

7. Ferrão-Filho, A.D.S.; Kozlowsky-Suzuki, B. Cyanotoxins: Bioaccumulation and Effects on Aquatic Animals. Mar. Drugs 2011, 9, 2729-2772. [CrossRef] [PubMed]

8. World Health Organization Guidelines for Drinking-Water Quality, Fourth Edition. Available online: http://www.who.int/water_sanitation_health/publications/2011/dwq_guidelines/en/ (accessed on 23 April 2017). 
9. EPA, U.S.E.P.A. Toxicological Review of Cyanobacterial Toxins: Microcystins LR, RR, YR and LA (External Review Draft). Available online: https://cfpub.epa.gov/ncea/risk/recordisplay.cfm?deid=160548\&CFID= 79569862\&CFTOKEN=96333965 (accessed on 11 April 2017).

10. EPA, U.S.E.P.A. Drinking Water Health Advisory for the Cyanobacterial Toxin Cylindrospermopsin. Available online: https://www.google.ch/url?sa=t\&rct=j\&q=\&esrc=s\&source=web\&cd=1\&ved= 0ahUKEwi4j-_yg7_TAhWrA8AKHQgBCzoQFggnMAA\&url=https\%3A\%2F\%2Fwww.epa.gov\%2Fsites\% 2Fproduction\%2Ffiles\%2F2015-06\%2Fdocuments\%2Fcylindrospermopsin-report-2015.pdf\&usg= AFQjCNE0OOTCg5ehEXmN0gZrMNcOUnfYeg\&cad=rja (accessed on 11 April 2017).

11. EPA Office of Water, U.S. Human Health Recreational Ambient Water Quality Criteria or Swimming Advisories for Microcystins and Cylindrospermopsin—Draft. Available online: https:/ /www.epa.gov/sites / production/files/2016-12/documents/draft-hh-rec-ambient-water-swimming-document.pdf (accessed on 23 April 2017).

12. Hitzfeld, B.; Höger, S.; Dietrich, D. Cyanobacterial toxins: Removal during drinking water treatment, and human risk assessment. Environ. Health Perspect. 2000, 108, 113. [CrossRef] [PubMed]

13. Chang, J.; Chen, Z.; Wang, Z.; Kang, J.; Chen, Q. Oxidation of microcystin-LR in water by ozone combined with UV radiation: The removal and degradation pathway. Chem. Eng. J. 2015, 276, 97-105. [CrossRef]

14. He, X.; Armah, A.; Hiskia, A.; Kaloudis, T.; O'Shea, K. Destruction of microcystins (cyanotoxins) by UV-254 $\mathrm{nm}$-based direct photolysis and advanced oxidation processes (AOPs): Influence of variable amino acids on the degradation kinetics and reaction mechanisms. Water Res. 2015, 74, 227-238. [CrossRef] [PubMed]

15. Pinho, L.; Azevedo, J.; Brito, Â.; Santos, A. Effect of $\mathrm{TiO}_{2}$ photocatalysis on the destruction of Microcystis aeruginosa cells and degradation of cyanotoxins microcystin-LR and cylindrospermopsin. Chem. Eng. J. 2015, 268, 144-152. [CrossRef]

16. Zhang, Y.; Shao, Y.; Gao, N.; Chu, W.; Sun, Z. Removal of microcystin-LR by free chlorine: Identify of transformation products and disinfection by-products formation. Chem. Eng. J. 2016, 287, 189-195. [CrossRef]

17. Liu, S.; Hu, X.; Jiang, W.; Ma, L.; Cai, M.; Xu, H.; Wu, M.; Ma, F. Degradation of Microcystins from Microcystis aeruginosa by 185-nm UV Irradiation. Water Air Soil Pollut. 2016, 227, 129. [CrossRef]

18. Chang, J.; Chen, Z.; Wang, Z.; Shen, J.; Chen, Q.; Kang, J. Ozonation degradation of microcystin-LR in aqueous solution: intermediates, byproducts and pathways. Water Res. 2014, 63, 52-61. [CrossRef] [PubMed]

19. Phujomjai, Y.; Somdee, A.; Somdee, T. Biodegradation of microcystin [Dha7]MC-LR by a novel microcystin-degrading bacterium in an internal airlift loop bioreactor. Water Sci. Technol. 2016, 73, 267-274. [CrossRef] [PubMed]

20. Pestana, C.; Edwards, C.; Prabhu, R.; Robertson, P. Photocatalytic degradation of eleven microcystin analogues and nodularin by $\mathrm{TiO}_{2}$ coated glass microspheres. J. Hazard. Mater. 2015, 300, 347-353. [CrossRef] [PubMed]

21. Ho, J.; Michalak, A. Challenges in tracking harmful algal blooms: A synthesis of evidence from Lake Erie. J. Great Lakes Res. 2015, 41, 317-325. [CrossRef]

22. De Rijcke, M.; Vandegehuchte, M.; Bussche, J. Common European Harmful Algal Blooms affect the viability and innate immune responses of Mytilus edulis larvae. Fish Shellfish Immunol. 2015, 47, 175-181. [CrossRef] [PubMed]

23. Selcuk, M.; Oksuz, L.; Basaran, P. Decontamination of grains and legumes infected with Aspergillus spp. and Penicillum spp. by cold plasma treatment. Bioresour. Technol. 2008, 99, 5104-5109. [CrossRef] [PubMed]

24. Dhayal, M.; Lee, S.; Park, S. Using low-pressure plasma for Carthamus tinctorium L. seed surface modification. Vacuum 2006, 80, 499-506. [CrossRef]

25. Hickling, A. Electrochemical Processes in Glow Discharge at the Gas-Solution Interface. In Modern Aspects of Electrochemistry No. 6; Springer: Boston, MA, USA, 1971; pp. 329-373.

26. Perni, S.; Shama, G.; Kong, M.G. Cold Atmospheric Plasma Disinfection of Cut Fruit Surfaces Contaminated with Migrating Microorganisms. J. Food Prot. 2008, 71, 1619-1625. [CrossRef] [PubMed]

27. Montie, T.; Kelly-Wintenberg, K. An overview of research using the one atmosphere uniform glow discharge plasma (OAUGDP) for sterilization of surfaces and materials. IEEE Trans. Plasma Sci. 2000, 28, 41-50. [CrossRef]

28. Sarangapani, C.; Misra, N.; Milosavljevic, V. Pesticide degradation in water using atmospheric air cold plasma. J. Water Process Eng. 2016, 9, 225-232. [CrossRef] 
29. Wang, H.; Chen, X. Kinetic analysis and energy efficiency of phenol degradation in a plasma-photocatalysis system. J. Hazard. Mater. 2011, 186, 1888-1892. [CrossRef] [PubMed]

30. Thirumdas, R.; Sarangapani, C.; Annapure, U.S. Cold Plasma: A novel Non-Thermal Technology for Food Processing. Food Biophys. 2014, 10,1-11. [CrossRef]

31. Misra, N.; Pankaj, S.; Walsh, T.; O'Regan, F. In-package nonthermal plasma degradation of pesticides on fresh produce. J. Hazard. Mater. 2014, 271, 33-40. [CrossRef] [PubMed]

32. Min, Z.W.; Hong, S.-M.; Mok, C.-K.; Im, G.-J. Degradation of the Selected Pesticides by Gas Discharge Plasma. Korean J. Pestic. Sci. 2012, 16, 11-20. [CrossRef]

33. Barillas, L. Design of a Prototype of Water Purification by Plasma Technology as the Foundation for an Industrial Wastewater Plant. J. Phys. Conf. Ser. 2015, 591, 12057. [CrossRef]

34. Lawton, L.; Marsalek, B.; Padisák, J.; Chorus, I. Determination of Cyanobacteria in the Laboratory. In Toxic Cyanobacteria Water: A Guid to Their Public Health Consequences, Monitoring and Management; St Edmundsbury Press: England, UK, 1999.

35. Fagan, R.; McCormack, D.E.; Dionysiou, D.D.; Pillai, S.C. A review of solar and visible light active $\mathrm{TiO}_{2}$ photocatalysis for treating bacteria, cyanotoxins and contaminants of emerging concern. Mater. Sci. Semicond. Process. 2016, 42, 2-14. [CrossRef]

36. Liu, I.; Lawton, L.A.; Robertson, P.K.J. Mechanistic studies of the photocatalytic oxidation of microcystin-LR: An investigation of byproducts of the decomposition process. Environ. Sci. Technol. 2003, 37, 3214-3219. [CrossRef] [PubMed]

37. Buthiyappan, A.; Abdul Aziz, A.R.; Wan Daud, W.M.A. Degradation performance and cost implication of UV-integrated advanced oxidation processes for wastewater treatments. Rev. Chem. Eng. 2015, 31, $263-302$. [CrossRef]

38. Hu, C.; Rea, C.; Yu, Z.; Lee, J. Relative importance of Microcystis abundance and diversity in determining microcystin dynamics in Lake Erie coastal wetland and downstream beach water. J. Appl. Microbiol. 2016, 120, 138-151. [CrossRef] [PubMed]

39. Watanabe, M.M.; Kawachi, M.; Hiroki, M.; Kasai, F. Microalgae and Protozoa. Microbial Culture Collections. In NIES Collection List of Strains, 6th ed.; National Institute for Environmental Studies: Tsukuba, Japan, 2000.

40. Rapala, J.; Erkomaa, K.; Kukkonen, J.; Sivonen, K.; Lahti, K. Detection of microcystins with protein phosphatase inhibition assay, high-performance liquid chromatography-UV detection and enzyme-linked immunosorbent assay: Comparison of methods. Anal. Chim. Acta 2002, 466, 213-231. [CrossRef]

41. Choi, H.; Antoniou, M.G.; de la Cruz, A.A.; Stathatos, E.; Dionysiou, D.D. Photocatalytic $\mathrm{TiO}_{2}$ films and membranes for the development of efficient wastewater treatment and reuse systems. Desalination 2007, 202, 199-206. [CrossRef]

42. Ohio EPA Total (Extracellular and Intracellular) Microcystins-ADDA by ELISA Analytical Methodology. Available online: https://www.google.ch/url?sa=t\&rct=j\&q=\&esrc=s\&source=web\&cd=1\&ved= 0ahUKEwiB4N6-hL_TAhVHIcAKHSnTBvkQFggiMAA\&url=http\%3A\%2F\%2Fepa.ohio.gov\%2FPortals\% 2F28\%2Fdocuments\%2Fhabs\%2FHAB_Analytical_Methodology.pdf\&usg=AFQjCNFNYAXrJr2Q-1M_ vlw_jL_pU2sOqg\&cad=rja (accessed on 11 April 2017).

43. Bolton, J.R.; Bircher, K.G.; Tumas, W.; Tolman, C.A. Figures-of-merit for the technical development and application of advanced oxidation technologies for both electric- and solar-driven systems (IUPAC Technical Report). Pure Appl. Chem. 2001, 73, 627-637. [CrossRef]

44. Zhang, H.; Huang, Q.; Ke, Z.; Yang, L.; Wang, X.; Yu, Z. Degradation of microcystin-LR in water by glow discharge plasma oxidation at the gas-solution interface and its safety evaluation. Water Res. 2012, 46, 6554-6562. [CrossRef] [PubMed]

45. Sampaio, M.; Silva, C.; Silva, A. Carbon-based $\mathrm{TiO}_{2}$ materials for the degradation of Microcystin-LA. Appl. Catal. B 2015, 170, 74-82. [CrossRef]

46. Xagoraraki, I.; Harrington, G.W.; Zulliger, K.; Zeier, B.; Krick, W.; Karner, D.A.; Standridge, J.H.; Westrick, J. Inactivation kinetics of the cyanobacterial toxin microcystin-LR by free chlorine. J. Environ. Eng. 2006, 132, 818-823. [CrossRef]

47. Qiao, R.P.; Li, N.; Qi, X.H.; Wang, Q.S.; Zhuang, Y.Y. Degradation of microcystin-RR by UV radiation in the presence of hydrogen peroxide. Toxicon 2005, 45, 745-752. [CrossRef] [PubMed]

48. Xin, Q.; Zhang, Y.; Wu, K. Degradation of Microcystin-LR by Gas-Liquid Interfacial Discharge Plasma. Plasma Sci. Technol. 2013, 15, 1221-1225. [CrossRef] 
49. Niedermeyer, T. Microcystin Congeners Described in the Literature. Available online: https://figshare.com/ articles/_Microcystin_congeners_described_in_the_literature/880756 (accessed on 8 March 2017).

50. EPA, U.S.E.P.A. Method 546: Determination of Total Microcystins and Nodularins in Drinking Water and Ambient Water by Adda Enzyme-Linked Immunosorbent Assay. Available online: https:/ /www.google.ch/url? $\mathrm{sa}=\mathrm{t} \& \mathrm{rct}=\mathrm{j} \& \mathrm{q}=\& \mathrm{esrc}=\mathrm{s} \&$ source $=$ web\&cd $=2 \& \mathrm{ved}=0 \mathrm{ahUKEwjQnJD5hL}$ TAhUsK8AKHdJDD2wQFggnMAE\& url=https \%3A\%2F\%2Fwww.epa.gov\%2Fsites\%2Fproduction\%2Ffiles\%2F2016-09\%2Fdocuments\%2Fmethod546-determination-total-microcystins-nodularins-drinking-water-ambient-water-adda-enzyme-linkedimmunosorbent-assay.pdf\&usg=AFQjCNHUb2XiT27dC0x3YawD5PgF0MRQlw\&cad=rja (accessed on 11 April 2017).

51. Tsuji, K.; Watanuki, T.; Kondo, F.; Watanabe, M.F.; Suzuki, S.; Nakazawa, H.; Suzuki, M.; Uchida, H.; Harada, K.I. Stability of microcystins from cyanobacteria-II. Effect of UV light on decomposition and isomerization. Toxicon 1995, 33, 1619-1631. [CrossRef]

52. Schnabel, U.; Sydow, D.; Schlüter, O.; Andrasch, M.; Ehlbeck, J. Decontamination of Fresh-Cut Iceberg Lettuce and Fresh Mung Bean Sprouts by Non-Thermal Atmospheric Pressure Plasma Processed Water (PPW). Modern Agric. Sci. Technol. 2015, 1, 23-39.

53. Pignata, C.; D’Angelo, D.; Fea, E.; Gilli, G. A review on microbiological decontamination of fresh produce with nonthermal plasma. J. Appl. Microbiol. 2017. [CrossRef] [PubMed]

54. Wang, R.X.; Nian, W.F.; Wu, H.Y.; Feng, H.Q.; Zhang, K.; Zhang, J.; Zhu, W.D.; Becker, K.H.; Fang, J. Atmospheric-pressure cold plasma treatment of contaminated fresh fruit and vegetable slices: inactivation and physiochemical properties evaluation. Eur. Phys. J. D 2012, 66, 276. [CrossRef]

55. Lee, J.; Lee, S.; Jiang, X. Cyanobacterial Toxins in Freshwater and Food: Important Sources of Exposure to Humans. Annu. Rev. Food Sci. 2017, 8, 281-304. [CrossRef] [PubMed]

(C) 2017 by the authors. Licensee MDPI, Basel, Switzerland. This article is an open access article distributed under the terms and conditions of the Creative Commons Attribution (CC BY) license (http:/ / creativecommons.org/licenses/by/4.0/). 